\title{
Христина КУЗьМА
}

\section{ВНУТРІШНІЙ КОНТРОЛЬ: СУТНІСТЬ ТА ОСОБЛИВОСТІ ОРГАНІЗАЦІЇ НА ПІДПРИЄМСТВАХ, ЯКІ ЗДІЙСНЮЮТЬ КОМІСІЙНІ ОПЕРАЦІЇ}

Досліджено трактування поняття «внутрішній контроль» різними вченими та запропоноване авторське визначення цього поняття. Виявлено, що важливою складовою в системі управління будь-яким підприємством є система внутрішнього контролю. Досліджено трактування терміну «система внутрішнього контролю» різними вченими та запропоноване авторське визначення цього терміну. Визначено роль системи внутрішнього контролю на підприємствах, які здійснюють комісійні операції. Встановлено, що ефективність проведення внутрішнього контролю на підприємстві, яке здійснює комісійні операції, в основному залежить від його правильної організації. Виділено три етапи проведення внутрішнього контролю на підприємствах, які здійснюють комісійні операції в результаті проведеного дослідження. Визначено, що найголовнішим етапом проведення внутрішнього контролю на підприємствах, які здійснюють комісійні операції, $\epsilon$ основний етап. Встановлено, що організація та проведення внутрішнього контролю на підприємствах комісійної торгівлі залежить від того, хто буде здійснювати контрольні процедури (комітент чи комісіонер). Досліджено проведення внутрішнього контролю комісійних операцій як комітентом, так і комісіонером. Визначено, що внутрішній контроль в діяльності комітента і комісіонера виконує різну роль. Виділено основні складові процесу здійснення внутрішнього контролю у комісіонера.

Використано загальнонаукові та спеціальні методи пізнання економічних явищ $і$ процесів: узагальнення, групування та порівняння, аналіз та ін.

Ключові слова: внутрішній контроль, підприємство, комісійні операції, система внутрішнього контролю, організація внутрішнього контролю.

\section{JEL: M 40}

Постановка проблеми. В сучасних економічних умовах ефективність діяльності підприємств, які здійснюють комісійні операції, значною мірою залежить від правильної організації внутрішнього контролю на підприємстві. Завдяки внутрішньому контролю керівництво може виявити основні недоліки, які впливають на діяльність та прийняття ефективних управлінських рішень, які покращать роботу підприємства. Внутрішній контроль присутній на кожному підприємстві, але не на кожному підприємстві вміють правильно організувати процес його здійснення, тому на сьогодні це питання не втрачає своєї актуальності й зумовлює подальші дослідження у цьому напрямі.

(C) Христина Кузьма, 2018. 
Аналіз останніх досліджень і публікацій. Внутрішній контроль, його сутність і організацію на підприємстві у своїх працях досліджували як вітчизняні, так і зарубіжні вчені, серед яких особливу увагу заслуговують праці таких науковців: Р. М. Воронка [2], І. В. Новик [14],П. О. Куцика [4; 11; 12], Дж. Робертсона, Г. Станкевич [15], Н. М. Бондаренко [1], Э. А. Аренса, Л. Г. Медвідь [4; 13], Т. О. Каменської [9], Р. В. Бойка, О. Г. Дроздової [6; 7], Г.В.Ковальової [10], В. І. Бачинського [11], М. М. Тарашевського [16], С. І. Головацької [3], Т. А. Жадан, С. О. Яценка [8] та ін. Однак організацію внутрішнього контролю на підприємстві, яке здійснює комісійні операції, на сьогодні досліджено на недостатньому рівні.

Метою статті є дослідити сутність внутрішнього контролю та його організацію на підприємствах, які здійснюють комісійні операції.

Виклад основного матеріалу дослідження. В економічній літературі науковці по-різному трактують поняття «внутрішній контроль». С. І. Головацька та Н. С. Хаймьонова вважають, що внутрішній контроль - це комплекс дій, правил та заходів, запроваджених керівництвом суб'єкта господарювання відповідного сектору економіки, що постійно застосовуються в ході діяльності організації 3 метою забезпечення впевненості у досягненні нею поставлених загальних цілей: результативності діяльності, економності та ефективності використання ресурсів; відповідності чинним нормативно-правовим та регулюючим документам, політиці та процедурам; незалежності та надійності інформації; захисту активів від втрат, зокрема тих, які виникли через зловживання, неврегульованість чи корупцію [3].

На сьогодні багато вчених розглядають внутрішній контроль як процес. Зокрема, такі науковці як Г. Станкевич, Н. М. Бондаренко, Т. О. Каменська та О. Ю. Редько вважають, що внутрішній контроль - це процес, який повинен реалізовуватися постійно повноважними органами управління, основною метою якого $є$ досягнення цілей підприємства (компанії) [1; 9; 15].

Г.В.Ковальова стверджує, що внутрішній контроль $є$ невід'ємним елементом кожної стадії процесу управління; відокремленою стадією, яка забезпечує інформаційну прозорість у якості ходу процесу управління на різних його стадіях [10].

«...На думку Т. А. Жадан та С. О. Яценка, внутрішній контроль варто розглядати «як сукупність форм, методів, інструментів та процедур контролю, за допомогою яких суб'єкт управління одержує інформацію про фрактичні показники фрінансовогосподарської діяльності підприємства, встановлюються відхилення цих показників від заданих або нормативних, виявляються причини цих відхилень та розробляються заходи для їх усунення або попередження в майбутньому» [8].

Так, П. О. Куцик вважає, що внутрішній контроль - це самостійна функція управління, яка виступає засобом налагодження зворотних зв'язків, завдяки чому управлінський персонал підприємства чітко простежує хід виконання прийнятих ним рішень. Це дає змогу своєчасно реагувати на відхилення в роботі підконтрольних центрів відповідальності від заданої мети й відповідно коригувати їх діяльність [12].

Водночас багато сучасних науковців розглядають внутрішній контроль як систему. Р. М. Воронко та М. М. Тарашевський стверджують, що внутрішній контроль - це регулююча система діяльності підприємства, основною метою якої $є$ своєчасне 
виявлення недоліків, застосування заходів щодо їх усунення, запобігання кризовим явищам і забезпечення ефективного ведення бізнесу [2; 16].

Такі вчені, як С. А. Кошкаров, П. О. Куцик та В. І. Бачинський вважають, що внутрішній контроль - це перевірка виконання ухвалених рішень, що дає можливість отримувати інфрормацію про функціонування ланок системи [11].

Внутрішній контроль трактує О. Г. Дроздова як невід'ємну складову системи управління, яка забезпечує ефективне функціонування господарської діяльності підприємства на належному рівні, за допомогою якої можна виявити недоліки при здійсненні тих чи інших операцій та надати рекомендації щодо їх вирішення [6].

П. О. Куцик, Л. Г. Медвідь, В. О. Шевчук та Д. О. Харинович-Яворська вважають, що внутрішній контроль на торговельних підприємствах має бути системою регулювання їх діяльності шляхом перевірки ходу реалізації планів, завдань, зіставлення фактичних результатів роботи зі встановленими бюджетними показниками [4, с. 162].

На наш погляд, внутрішній контроль на підприємстві, яке здійснює комісійні операції,виступаєоднією із головних функцій управління підприємством, завдяки якій керівництво може виявити недоліки в діяльності, причини їх виникнення та прийняти ефрективні управлінські рішення, які сприятимутьпокращеннюроботи підприємства.

Важливою складовою в системі управління будь-яким підприємством є система внутрішнього контролю.

Система внутрішнього контролю - це сукупність методик і процедур, прийнятих керівництвом економічного суб'єкта для впорядкованого та ефективного ведення господарської діяльності, що, зокрема, включає організовані нагляд і перевірку всередині даного суб'єкта [9, с. 10].

Г. Станкевич та О. М. Домбик вважають, що система внутрішнього контролю являє собою політику і процедури, прийнятіуправлінським персоналом суб'єкта господарювання для досягнення цілей щодо забезпечення ефективного ведення господарської діяльності, у тому числі дотримання політики системи управління, забезпечення збереження активів, запобігання шахрайству та помилкам, їх виявлення, забезпечення точності та повноти облікових записів, забезпечення своєчасної підготовки достовірної інформації [5; 15].

Проведене дослідженнядозволяє зробити висновок, що система внутрішнього контролю на підприємстві, яке здійснює комісійні операції, - це сукупність правил та процедур, які встановлені керівництвомз метою здійснення ефективної та впорядкованої господарської діяльності.

Якщо на підприємстві, яке здійснює комісійні операції, буде відсутня система внутрішнього контролю, то це призведе до переміщення контролю в режим спостереження і самоконтролю та до його спрощення. В результаті цього, підприємство отримує велику кількість непокритих залишкових ризиків, які спричиняють втрату частини активів.

В основному на підприємстві, яке здійснює комісійні операції, організація внутрішнього контролю залежить від можливостей інформаційної бази та методичного забезпечення. 
Систему внутрішнього контролю кожнепідприємство, яке здійснює комісійні операції,організовує самостійно 3 метою прийняття раціональних управлінських рішень та перевірки їх виконання у майбутньому.

Закордоном систему внутрішнього контролю застосовують по-різному, це залежить від економічного розвитку країни, встановлених норм, традицій і звичаїв. Залежно від особливостей країни на підприємствах застосовують різні моделі внутрішнього контролю.Загалом науковці у своїх дослідженнях виокремлюють три моделі корпоративного управління: англо-американську, західноєвропейську і японську. Але на основі проведених досліджень виявлено, що в чистому вигляді в коопераціях жодну модель не застосовують, переважно кооперації поєднують різні моделі в залежності від специфріки їх діяльності.

На наш погляд, система внутрішнього контролю буде ефективною в тому випадку, коли вона буде гнучкою, задовольнятиме інтереси всіх рівнів управління та враховуватиме всі особливості діяльності підприємства.

Ефективність проведення внутрішнього контролю на підприємстві, яке здійснює комісійні операції, в основному залежить від його правильної організації.

На основі проведеного дослідження нами виокремлено основні етапи організації внутрішнього контролю на підприємствах, які здійснюють комісійні операції (рис. 1).

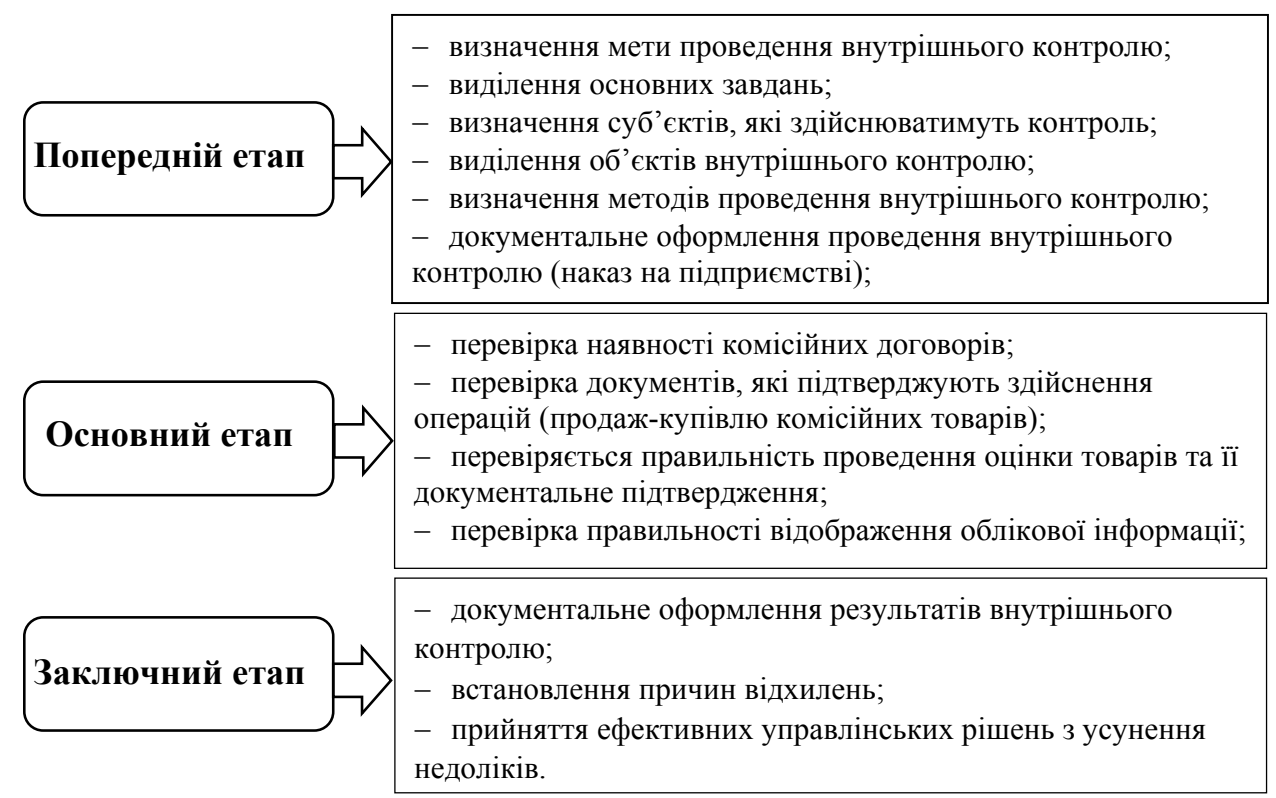

Рис. 1. Організація процесу здійснення внутрішнього контролю на підприємствах, які здійснюють комісійні операції

Джерело: розроблено автором.

На попередньому етапі внутрішнього контролю визначається мета проведення контролю для ефективного використання його процедур. 
На цьому етапі також визначаються основні завдання внутрішнього контролю, які потребують вирішення. Для проведення внутрішнього контролю потрібно визначити суб'єкти та об'єкти дослідження. Також на цьому етапі визначаються основні методи, які будуть застосовуватися при проведенні внутрішнього контролю. Зокрема на підприємствах, які здійснюють комісійні операції, застосовуються розрахунковоаналітичні, документальні та органолептичні методичні прийоми. На цьому етапі проведення внутрішнього контролю на підприємстві, яке здійснює комісійні операції, оформляється відповідним наказом керівника (директора) підприємства.

Основний етап внутрішнього контролю $є$ найголовнішим, оскільки саме на цьому етапі перевіряється: відповідність товарів певним вимогам, сертифікатам; наявність первинних документів на комісійні товари (квитанцій, товарних ярликів, цінників, оцінно-здавальної відомості тощо); правильність відображення облікової інформації в регістрах бухгалтерського обліку.

На заключному етапі підбиваються підсумки результатів внутрішнього контролю, узагальнюються висновки та приймаються певні управлінські рішення.

Підприємства, які здійснюють комісійні операції, $€$ специфічними, оскільки по-перше, вони здійснюють свою діяльність на основі договорів комісії, які регламентуються Цивільним кодексом України, по-друге, відображення операцій з комісійними товарами в бухгалтерському обліку має свої особливості.

На підприємствах комісійної торгівлі організація та проведення внутрішнього контролю залежить від того, хто буде здійснювати контрольні процедури (комітент чи комісіонер).

Внутрішній контроль у діяльності комітента і комісіонера виконує різну роль. Комітент як власник товару зацікавлений у тому, як розпорядяться його майном, а комісіонер зацікавлений в ефективності діяльності підприємства комісійної торгівлі, оскільки від цього безпосередньо залежить його дохід. Оскільки комітент і комісіонер мають різну мету, то об'єкти внутрішнього контролю для комітента й комісіонера будуть відрізнятися.

Комітент у своїй діяльності здійснює контроль при передачі товарів на комісію (перевіряє стан товару, його комплектність та відповідність до переліку товару, який приймається на комісію) (рис. 2). Під час проведення внутрішнього контролю комітент насамперед повинен перевірити правильність отриманого доходу від продажу переданого на комісію товару. У комітента внутрішній контроль розглядається тільки тоді, коли він $є$ юридичною особою і виступає як власник товару.

О. Г. Дроздова процес здійснення внутрішнього контролю у комітента поділяє на такі складові:

- внутрішній контроль господарських процесів основної його діяльності;

- контроль у розрізі переданих на комісію товарів;

- зовнішній контроль виконання умов договору з приводу реалізації товару комісіонером [7].

Щодо комісіонера, то основними об'єктами внутрішнього контролю для нього є: відповідність товару певним вимогам та документам, вартість прийнятого товару на комісію та можливість його продажу (рис. 3). 


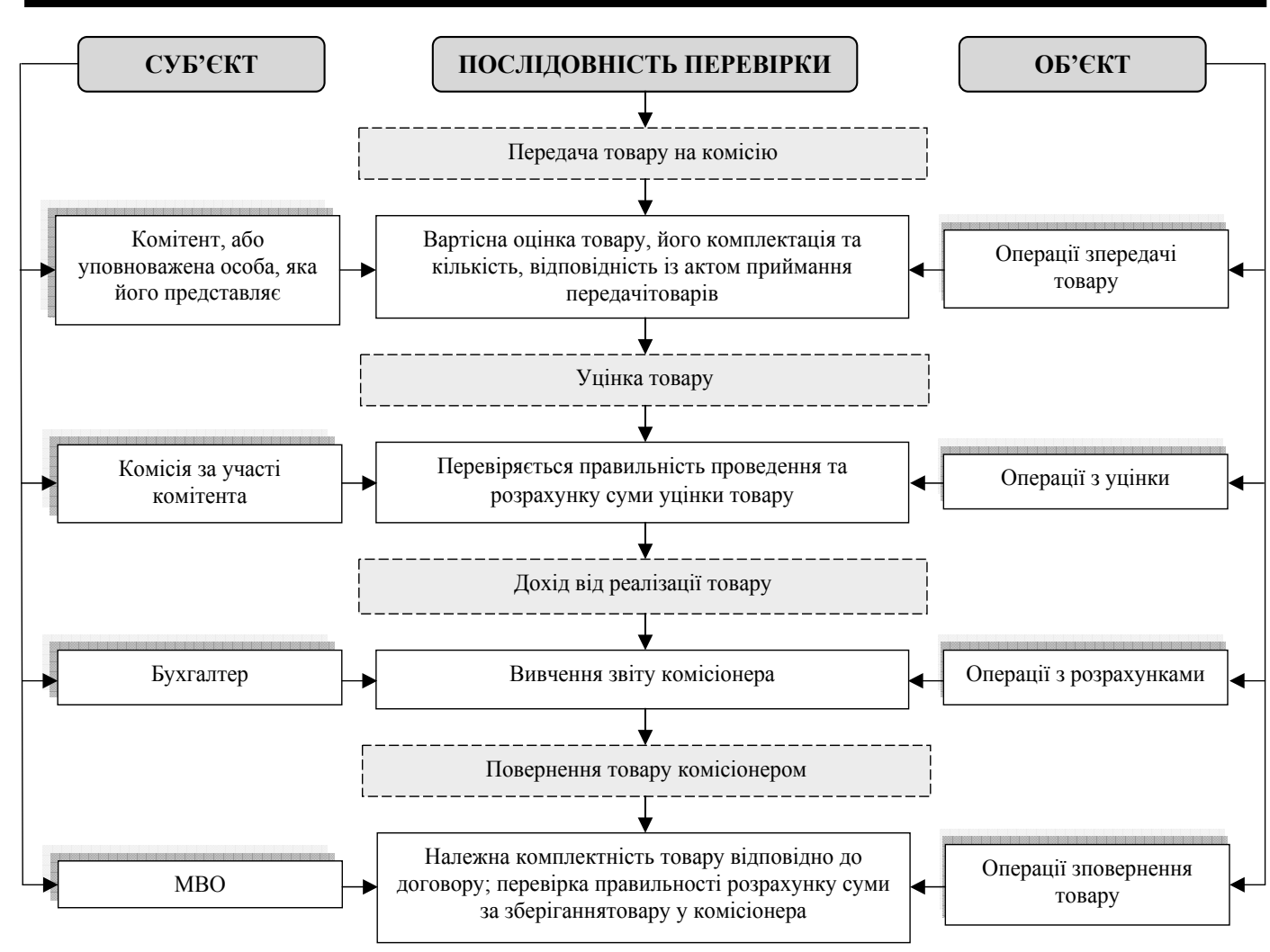

Рис. 2. Проведення внутрішнього контролю комісійних операцій у комітента

Джерело: розроблено автором на основі [7].

Оскільки згідно з Цивільним кодексом України комісіонер повинен діяти тільки виключно в інтересах комітента, тому він зацікавлений реалізувати товар за тією ціною, яка підходить комітенту.

В комісійній торгівлі операцій з товарами є дуже багато, тому їх групують і поділяють на певні етапи. На наш погляд, внутрішній контроль слід здійснювати відповідно до виділених етапів.

У результаті проведеного дослідження ми виділили основні складові процесу здійснення внутрішнього контролю у комісіонера: контроль при прийнятті товарів на комісію, контроль при передачі товарів зі складу в торговельний зал, контроль при продажі товару та контроль виконання умов договору з приводу реалізації товару комітента. 


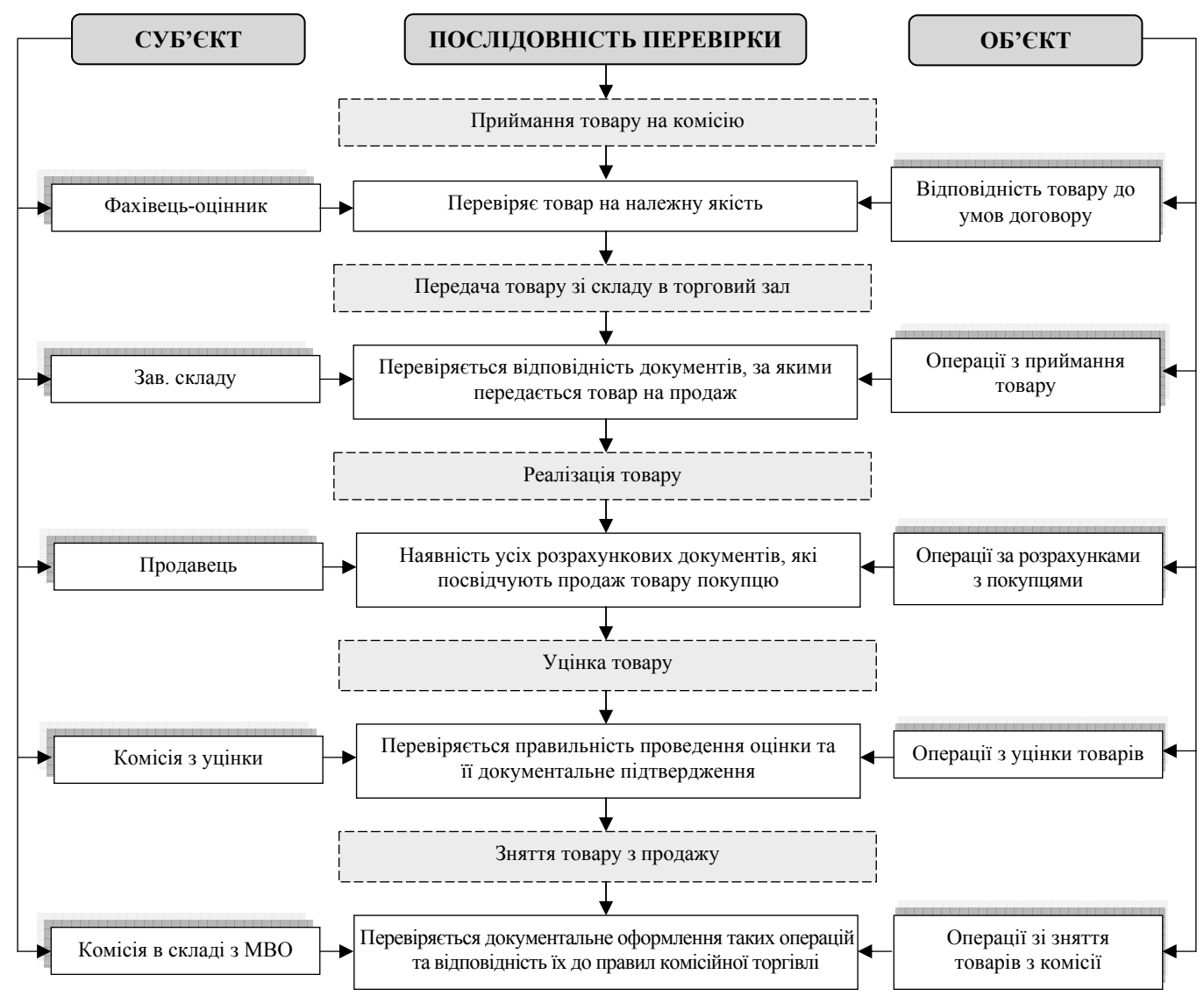

\section{Рис. 3. Проведення внутрішнього контролю комісійних операцій у комісіонера}

Джерело: розроблено автором на основі [7].

Висновки. Отже, внутрішній контроль на підприємстві, яке здійснює комісійні операції, - одна із головних функцій управління підприємством, завдяки якій керівництво може виявити недоліки в діяльності, причини їх виникнення та прийняти ефрективні управлінські рішення, які сприятимуть покращенню роботи підприємства.

Система внутрішнього контролю на підприємстві, яке здійснює комісійні операції, це сукупність правил та процедур, які встановлені керівництвом з метою здійснення ефрективної та впорядкованої господарської діяльності.

На основі проведеного дослідження ми можемо зробити висновок, що внутрішній контроль на підприємстві, яке здійснює комісійні операції, має багато особливостей, тому при організації внутрішнього контролю потрібно приділяти особливу увагу як комітенту, так і комісіонеру.

Ми вважаємо, що на основі отриманих результатів дослідження доцільно розробити Положення про організацію внутрішнього контролю на підприємстві, яке здійснює 
комісійні операції. Це Положення забезпечить безперервний обмін інформацією між різними рівнями управління, а також допоможе швидко діяти при певних критичних ситуаціях, які можуть виникнути в результаті діяльності.

Перспективи подальших досліджень. Подальші дослідження мають бути спрямовані на визначення методики проведення внутрішнього контролю на підприємствах, які здійснюють комісійні операції.

\section{Список використаних джерел}

1. Бондаренко Н. М. Організація внутрішньогосподарського контролю використання основних засобів на вітчизняних підприємствах та шляхи його вдосконалення / Н. М. Бондаренко, Ю. К. Шачаніна // Науковий вісник Херсонського державного університету, 2017. - Вип. 23. Ч. 3. - С. 119-122. (Сер. «Економічні науки»).

2. Воронко Р. М. Внутрішній контроль як невід'ємна складова системи управління підприємств та організацій споживчої кооперації / Р. М.Воронко // Науковий вісник Ужгородського університету, 2015. - Вип. 1 (45). T. 2. С. 376-381. - (Сер. «Економіка»).

3. Головацька С. І. Організаційно-методична модель внутрішнього контролю витрат підприємства / С. І.Головацька, Н. С. Хаймьонова // економічні науки, 2015. - Вип. 12 (45). 4. 1. - С. 74-80. - (Сер. «Облік і фрінанси»).

4. Діяльність торговельних підприємств у конкурентному середовищі: контрольно-аналітичне забезпечення управління : моногр. / П. О. Куцик, Л. Г. Медвідь, В. О. Шевчук, Д. О. Харинович-Яворська. - Чернівці : Технодрук, 2015. $-370 \mathrm{c}$.

5. Домбик О. М. Організація внутрішнього контролю на підприємствах готельно-ресторанного бізнесу: теоретико-практичний аспект / О. М. Домбик // Науковий вісник НЛТУ України, 2016. - Вип. 26.2. - С. 47-53.

6. Дроздова О. Г.Особливості організації внутрішньогоконтролю руху товарів / О. Г. Дроздова // Зовнішня торгівля: економіка, фрінанси, право, 2015. - № 1 (78). - С. 121-130. - (Сер. «Економічні науки»).

7. Дроздова О. Г. Особливості організаціїта здійснення внутрішнього контролю на комісійних торговельних підприємствах / О. Г. Дроздова // Проблеми теорії таметодологіїбухгалтерського обліку, контролюіаналізу, 2012. -Вип. 2(23).C. 81-86.

8. Жадан Т. А. Внутрішній контроль як економічна категорія: систематизація наукових підходів та уточнення змісту / Т. А. Жадан, С. О. Яценко // Глобальні та національні проблеми економіки, 2017. - Вип. 16. - С. 845-850.

9. Каменська Т. О. Внутрішній контроль і аудит в управлінні: практичний посібник / Т. О. Каменська, О. Ю. Редько. - К. : ДП «Інфрормаційно-аналітичне агентство», 2015. - $375 \mathrm{c}$.

10. Ковальова Г. В. Роль внутрішнього контролю в системі управління господарською діяльністю підприємства / Г. В. Ковальова // Збірник наукових праць Таврійського державного агротехнологічного університету (економічні науки), 2013. - № 1(1). - С. 240-247. 
11. Куцик П. О. Внутрішньогосподарський оперативний облік і контроль у системі управління діяльністю виробничих підприємств : монографрія / С. А. Кошкаров, П. О. Куцик, В. І. Бачинський. - Чернівці : Золоті литаври, 2012. -259 c.

12. Куцик П. О. Внутрішній контроль розрахункових операцій в системі управління будівельним підприємством / П. О.Куцик // Вісник Львівської комерційної академії, 2013. - Вип. 42. - С. 116-122. - (Сер. економічна).

13. Медвідь Л. Г. Удосконалення внутрішнього контролю як складової управління торговельним підприємством / Л. Г. Медвідь, Д. О. Харинович-Яворська // Науковий вісник НЛТУ України: зб. наук. техн. праць, 2015. - Вип. 25.1. C. 307-314.

14. Новик І. В. Організація системи внутрішнього контролю на підприємстві І. В. Новик // Наукові записки, 2017. - Вип. 2 (55). - С. 188-196.

15. Станкевич Г. Особливості системи внутрішнього контролю підприємства та роботи внутрішнього аудитора / Г. Станкевич // Аудитор України. Методика та практика аудиту, 2014. - № 9 (226). - С. 32-37.

16. Тарашевський М. М. Система внутрішнього контролю: сутність, складові, еволюція / М. М. Тарашевський // Водний транспорт, 2016. - Вип. 2. С. $181-187$.

\section{References}

1. Bondarenko N. M., Shachanina Yu. K. Orhanizatsiia vnutrishnohospodarskoho kontroliu vykorystannia osnovnykh zasobiv na vitchyznianykh pidpryiemstvakh ta shliakhy yoho vdoskonalennia [Internal control over using fixed assets in domestic enterprises and ways to improve it]. Naukovyi visnyk Khersonskoho derzhavnoho universytetu - Scientific Herald of Kherson State University, 2017, Issue 23, Chapter 3, p. 119-122 [in Ukrainian].

2. Voronko R. M. Vnutrishnii kontrol yak nevidiemna skladova systemy upravlinnia pidpryiemstv ta orhanizatsii spozhyvchoi kooperatsii [Internal control as an integral part of enterprise management and consumer co-operation]. Naukovyi visnyk Uzhhorodskoho universytetu $\square$ Scientific Herald of Uzhgorod University, 2015, Issue 1 (45), Vol. 2, p. 376-381[in Ukrainian].

3. Holovatska S. I., Khaimonova N. S. Orhanizatsiino-metodychna model vnutrishnoho kontroliu vytrat pidpryiemstva [Organizational and methodical model of internal control over expenses of enterprises]. Ekonomichni nauky. Seriia "Oblik i finansy» $\square$ Economic Sciences. Series «Accounting and Finance», 2015, Issue 12 (45), Chapter 1, p. 74-80 [in Ukrainian].

4. Kutsyk P. O., Medvid L. H., Shevchuk V. O., Kharynovych-Yavorska D. O. Diialnist torhovelnykh pidpryiemstv u konkurentnomu seredovyshchi: kontrolno-analitychne zabezpechennia upravlinnia: monohr. [Activities of trading enterprises in a competitive environment: control and analytical management support: monograph]. Chernivtsi: Tekhnodruk, 2015, 370 p. [in Ukrainian].

5. Dombyk O. M. Orhanizatsiia vnutrishnoho kontroliu na pidpryiemstvakh hotelnorestorannoho biznesu: teoretyko-praktychnyi aspekt [The organization of internal 
control in enterprises of hotel and catering business: theoretical and practical aspects]. Naukovyi visnyk NLTU - Scientific Bulletin of UNFU, 2016, Issue 26(2), p. 47-53 [in Ukrainian].

6. Drozdova O. H. Osoblyvosti orhanizatsii vnutrishnohokontroliu rukhu tovariv [Features of organization of internal control over flow of goods]. Zovnishnia torhivlia: ekonomika, finansy, pravo - Foreign Trade: economics, finance, law, 2015, No. 1(78), p. 121-130 [in Ukrainian].

7. Drozdova O. H. Osoblyvosti orhanizatsii ta zdiisnennia vnutrishnoho kontroliu na komisiinykh torhovelnykh pidpryiemstvakh [Features or organization and maintenance of internal control in enterprises of commission trade]. Problemy teorii ta metodolohii bukhhalterskoho obliku, kontroliu i analizu - Problems of Theory and Methodology of Accounting, Control and Analysis, 2012, Issue 2(23), p. 81-86 [in Ukrainian].

8. Zhadan T. A., Yatsenko S. O. Vnutrishnii kontrol yak ekonomichna katehoriia: systematyzatsiia naukovykh pidkhodiv ta utochnennia zmistu [Internal control as an economic category: systematization of research approaches and revision of the concept]. Hlobalni ta natsionalni problemy ekonomiky - Global and National Problems of the Economy, 2017, Issue 16, p. 845-850 [in Ukrainian].

9. Kamenska T. O., redko O. Yu. Vnutrishnii kontrol i audyt v upravlinni: praktychnyi posibnyk [Internal control and audit in management: a practical guide]. Kyiv: DP «Informatsiino-analitychne ahentstvo», 2015, 375 p. [in Ukrainian].

10. Kovalova H. V. Rol vnutrishnoho kontroliu v systemi upravlinnia hospodarskoiu diialnistiu pidpryiemstva [The role of internal control in management of economic activities of enterprises]. Zbirnyk naukovykh prats Tavriiskoho derzhavnoho ahrotekhnolohichnoho universytetu (ekonomichni nauky) - Collection of scientific papers of Tavria State Agritechnological University (Economics), 2013, No. 1(1), p. 240-247 [in Ukrainian].

11. Kutsyk P. O., Koshkarov S. A., Bachynskyi V. I. Vnutrishnohospodarskyi operatyvnyi oblik i kontrol u systemi upravlinnia diialnistiu vyrobnychykh pidpryiemstv: monohrafiia [Internal operating accounting and control in management of economic activities of manufacturing enterprises: monograph]. Chernivtsi: Zoloti lytavry, 2012, 259 p. [in Ukrainian].

12. Kutsyk P. O. Vnutrishnii kontrol rozrakhunkovykh operatsii v systemi upravlinnia budivelnym pidpryiemstvom [Internal control over payment operations in management of construction enterprises]. Visnyk Lvivskoi komertsiinoi akademii Bulletin of Lviv Commercial Academy, 2013, Issue 42, p. 116-122[in Ukrainian].

13. Medvid L. H., Kharynovych-Yavorska D. O. Udoskonalennia vnutrishnoho kontroliu yak skladovoi upravlinnia torhovelnym pidpryiemstvom [The improvement of internal control as a part of management of trade enterprises]. Naukovyi visnyk NLTU Scientific Bulletin of UNFU, 2015, Issue 25.1, p. 307-314 [in Ukrainian].

14. Novyk I. V. Orhanizatsiia systemy vnutrishnoho kontroliu na pidpryiemstvi [The organization of internal control in enterprises]. Naukovi zapysky - Scientific Papers, 2017, Issue 2 (55), p. 188-196 [in Ukrainian]. 
15. Stankevych $\mathrm{H}$. Osoblyvosti systemy vnutrishnoho kontroliu pidpryiemstva ta roboty vnutrishnoho audytora [Features of the system of internal control in enterprises and robots of internal audit]. Audytor Ukrainy: metodyka ta praktyka audytu - Audit of Ukraine: Methods and Practice, 2014, No. 9 (226), p. 32-37 [in Ukrainian].

16. Tarashevskyi M. M. Systema vnutrishnoho kontroliu: sutnist, skladovi, evoliutsiia [The system of internal control: the substance, components and evolution]. Vodnyi transport - Water Transport, 2016, Issue 2, p. 181-187 [in Ukrainian].

Редакція отримала матеріал 12 листопада 2018 p. 